\title{
振動する建物内を昇降するエレベータにおけるコンペンロープの かご室位置と加速度に基づいた張力付加によるアクティブ振動制御
}

三浦 奈々子*1，曽根 彰*2

\section{Active vibration control of compensation rope by tension based on elevator car position and acceleration during operation of an elevator in a vibrating building}

\author{
Nanako MIURA ${ }^{* 1}$ and Akira SONE*2

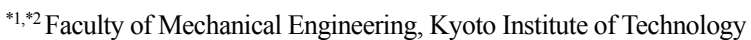 \\ Gosyokaido-cho, Matsugasaki, Sakyo-ku, Kyoto 606-8585, Japan
}

Received: 27 February 2018; Revised: 2 May 2018; Accepted: 18 July 2018

\begin{abstract}
In Japan, elevator cannot be used during an earthquake, and out-of-service hours tend to be long after large earthquake. It leads to difficulty in evacuation, rescue, and so on. Thus, it is important to suppress vibration of the whole elevator system during operation of an elevator in a vibrating building. In this paper, a vibration control method of compensation rope is proposed as a first step. Considering feedback control, responses are used to compute control force. However, response measurement or response estimation of the rope is too difficult to keep enough accurate. The proposed control method doesn't require the rope response but elevator car position and acceleration. First, an analysis model is derived by a partial differential equation. Then, control methods based on time-varying natural frequencies of the rope are formulated. Finally, the effectiveness compared with constant tension cases is verified. Two car motions, upward motion and downward motion, are analyzed in a vibrating building. It is confirmed that vibration responses are suppressed by avoiding resonance condition. By contrast, as raising tension method cannot reduce the initial tension by compensation rope's own weight and a compensating sheave weight, the relation between the initial natural frequency of the rope and the frequency of external force effects the control performance.
\end{abstract}

Keywords : Elevator, Compensation rope, Vibration control, Time-varying system, Active control, Tension

\section{1. 緒言}

超高層建物の建設が世界的に広がっており，建物内の縦方向の移動手段としてエレベータの役割は重要度を増 している，一方で，地震によりエレベータが損傷する事例が多く報告されている(社団法人日本エレベータ協会， 2012). エレベータの昇降路内には，かご室の昇降に伴って移動するメインロープやコンペンロープ，ケーブル等 の長尺物がある．これらの長尺物は地震時には建物の振動により大きく振動することがある．超高層建物では建 物の固有振動数とエレベータロープの固有振動数が低次モードで近接するため, エレベータロープは振動しやす い. これはロープスウェイ問題と呼ばれている. この振動が大きくなると, 昇降路のレールブラケットや昇降路 内設置機器の取り付け金具等の突出物に，長尺物が接触し引つ掛かる被害が発生する.

著者らはこれまでに，地震時管制運転によりエレベータが稼動していない状態を想定し，エレベータ機能の早 期復旧および損傷低減のための最大応答の低減や振動の継続時間の短縮を目的とした振動制御手法の提案を行っ てきた(例えば三浦, 小檜山, 2011). しかし，長周期地震動に共振した高層建物の振動は長く継続し，ロープの振 動も長く継続する. また, 巨大地震後には余震も多く発生し, 現状の対策ではエレベータの停止状態は長く継続 することが必要となる。したがって，エレベータロープの振動をエレベータが使用できるレベルの振動に抑えつ つ運用することが，今後，地震時や余震の続く中においてエレベータを利用した消火，救援，避難のための縦導

No.18-00108 [DOI: 10.1299/transjsme.18-00108], J-STAGE Advance Publication date : 30 July, 2018

*1 正員, 京都工芸䋊維大学 機械工学系（下606-8585 京都府京都市左京区松ヶ崎御所海道町）

*2 正員, フェロー, 京都工芸繊維大学 機械工学系

E-mail of corresponding author: miura-n@kit.ac.jp 
線の確保に繋がるものと考える. 火災時を対象とするものであるが, 東京消防庁は 2013 年に, 避難にエレベータ を活用するという指針を示している (東京消防庁，2017)。これは住民の高齢化とマンションの高層化がともに進 んでいるためである.

昇降するエレベータのロープ振動に対して，例えば，大㭇らは 5 点の計測センサ情報を用いた非定常ロバスト 制御手法の有効性を示している(大槻他, 2005). また，著者らもこれまでに，時間変動するエレベータシステムに 対して，振動するロープの振幅を状態量としてフィードバックして制御する方法を提案してきた(Nguyen et al., 2017). しかし，ロープの振動制御において振動するロープの応答を逐次正確に計測あるいは推定しフィードバッ ク制御を行うことは，センサ設置コストや通信・計測面から困難と考えられる．そこで本研究では，現在地震時 管制運転により停止することとなっている地震レベルかつ, 建物振動が線形とみなせる範囲（本論では層間変形 角 1/200 rad 未満）の運行において, かご室の位置および加速度の情報をもとに振動制御を行う方法を提案する.

本論ではまず，エレベータのコンペンロープを対象とし，コンペンシーブに取り付けたアクティブ制御器を用 いてコンペンロープ張力を制御し振動抑制を行う解析モデルを作成する. そしてかご室の昇降に伴うコンペンロ ープの固有振動数変化に着目した制御力を定式化し，かご室が上昇するときと下降するときについて制振性能を 検証する.

\section{2. アクティブ制御器を含むコンペンロープの振動モデル}

アクティブ制御器を含むコンペンロープの振動モデルを図 1 に示す. 図 1(a)では, 本論でモデル化される要素 を黒で示しており，(b)はそのモデルである. コンペンロープはコンペンシーブを介してかご室側と釣合錘側に存 在し，その両者に制御力が加えられる．本論では振止枠などパッシブな振動抑制方法で振幅を抑えることが，か ご室および釣合錘の昇降スペース確保の関係上，より難しいと考えられるかご室側のコンペンロープを制御対象 とする. 本論の数式において斜体はスカラーを, 太字の立体は行列あるいはベクトルを表している. まず, 時間 変化するコンペンロープの全長を $l(t)$ とおく. 時刻 $t$ におけるコンペンシーブから長さ $y(0 \leq y \leq l(t))$ の位置で のコンペンロープの張力 $T(y, t)$ は式（1）で表される.

$$
T(y, t)=\frac{m_{\mathrm{cs}}}{2} g+\rho y\{g-a(t)\}+u(t)
$$

ここで, $m_{\mathrm{cs}}$ はコンペンシーブの質量, $g$ は重力加速度 $\left(9.8 \mathrm{~m} / \mathrm{s}^{2}\right), \rho$ はコンペンロープの線密度, $a(t)$ は式 $(2)$ で 表されるかご室の昇降に伴うコンペンロープの鉛直方向の加速度, $u(t)$ はアクティブ制御器による下向きの制御

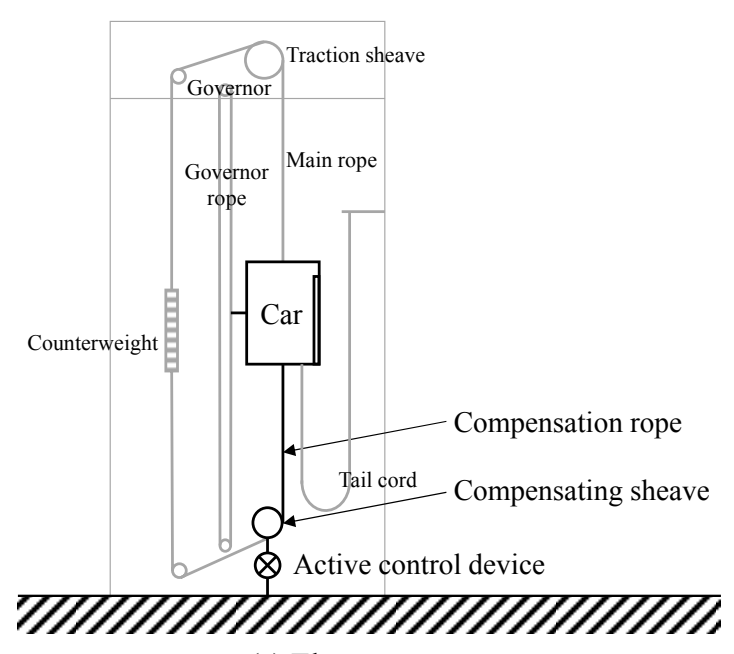

(a) Elevator system

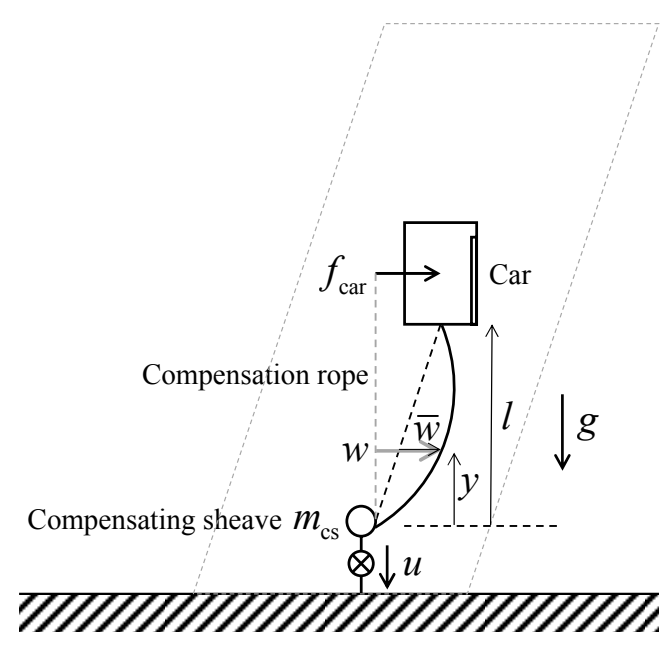

(b) Analysis model with active control device

Fig. 1 Compensation rope model with an active control device. In figure (a), analysis objects are shown with black color. As shown in figure (b), $w$ is a relative displacement from ground surface which is sum of building response and relative response of the rope $\bar{w}$. 
力（張力）である.

$$
a(t)=\frac{\partial^{2} l(t)}{\partial t^{2}}
$$

このとき，コンペンロープのロープスウェイ，すなわち水平方向の運動に関する運動方程式は，コンペンロープ の水平方向変位 $w(y, t)$ を用いて, 次のエレベータロープの一般的な偏微分方程式モデル(Benosman, 2014)で表す.

$$
\rho\left\{\frac{\partial^{2}}{\partial t^{2}}+v^{2}(t) \frac{\partial^{2}}{\partial y^{2}}+2 v(t) \frac{\partial^{2}}{\partial y \partial t}+a(t) \frac{\partial}{\partial y}\right\} w(y, t)-\frac{\partial}{\partial y} T(y, t) \frac{\partial w(y, t)}{\partial y}+c_{\mathrm{p}}\left\{\frac{\partial}{\partial t}+v(t) \frac{\partial}{\partial y}\right\} w(y, t)=0
$$

ここで， $c_{\mathrm{p}}$ は単位長さあたりのロープの減衰係数，v(t)はコンペンロープの速度である.

$$
v(t)=\frac{\partial l(t)}{\partial t}
$$

次に，コンペンロープに作用する外乱（変位）を考える，コンペンロープ上端はかご室に，下端はコンペンシ 一ブに接続しているため, 外乱としてはかご室の振動 $f_{\mathrm{car}}(t)$ とコンペンシーブの振動 $f_{\mathrm{cs}}(t)$ が考えられる.

$$
\begin{aligned}
& w(0, t)=f_{\mathrm{cs}}(t) \\
& w(l(t), t)=f_{\mathrm{car}}(t)
\end{aligned}
$$

ただし，建物基礎部とコンペンシーブの距離は，建物基礎部とかご室の距離と比較して極めて小さいため，本論 では建物基礎部とコンペンシーブの水平距離は振動中に変化しないものと仮定する.

$$
f_{\mathrm{cs}}(t)=0
$$

したがって，コンペンロープの水平方向変位 $w(y, t)$ は，コンペンロープの振動中心に対するコンペンロープの水 平方向の相対変位 $\bar{w}(y, t)$ と次式の関係を有する.

$$
w(y, t)=\bar{w}(y, t)+\frac{y}{l(t)} f_{\text {car }}(t)
$$

ここで，図 1(b)のようにコンペンロープの振動中心を直線状と仮定しており，式（8）の右辺第 2 項は近似式であ る. 建物とエレベータを連成系で考えることも可能である(例えば，三浦，小檜山，2011)が，本研究ではかご室お 
よびエレベータロープの振動が建物応答に与える影響は小さいと考え, エレベータのみで立式するモデルとする. $\bar{w}(y, t)$ についての境界条件は次式で表される.

$$
\bar{w}(0, t)=0
$$

$$
\bar{w}(l(t), t)=0
$$

次に，コンペンロープの相対変位 $\bar{w}(y, t)$ を $N$ 個のモード形状の重㸚合わせとして式（11）のように表す.

$$
\bar{w}(y, t)=\sum_{j=1}^{N} q_{j}(t) \varphi_{j}(\xi)
$$

ここで $q_{j}(t)$ は $j$ 次モードの刺激係数, $\varphi_{j}(\xi)$ は $j$ 次のモード形状の, 位置 $y(t)$ に対応する箇所 $\xi(0 \leq \xi \leq 1)$ の 值である. 実際にはロープ下部の方が上部と比較して張力が小さいため, コンペンロープのモード形状は下方で 膨らむ形状となる傾向があることが示されている(木村, 2013)が，本論では簡単のため，モード形状 $\varphi_{j}(\xi)$ を正 弦波と仮定して式（12）で表す.したがって， $\varphi_{j}(\xi)$ は式（14）に示すような直交性を有しており，その導関数 についても直交性を有する，なお，基準化のため正弦波の振幅を $\sqrt{2}$ としている.

$$
\varphi_{j}(\xi)=\sqrt{2} \sin (j \pi \xi)
$$

$$
\int_{0}^{1} \varphi_{j}^{2}(\xi) d \xi=2 \int_{0}^{1} \sin ^{2}(j \pi \xi) d \xi=2\left[\frac{\xi}{2}-\frac{1}{4 j \pi} \sin (2 j \pi \xi)\right]_{0}^{1}=1
$$

$$
\begin{aligned}
& \int_{0}^{1} \varphi_{j}(\xi) \varphi_{i}(\xi) d \xi=2 \int_{0}^{1} \sin (j \pi \xi) \sin (i \pi \xi) d \xi=\left[\frac{1}{(j-i) \pi} \sin (j-i) \pi \xi-\frac{1}{(j+i) \pi} \sin (j+i) \pi \xi\right]_{0}^{1}=0 \\
& \forall j \neq i
\end{aligned}
$$

$$
\xi=\frac{y}{l(t)}
$$

$$
\begin{aligned}
& \frac{\partial \xi}{\partial y}=\frac{1}{l(t)} \\
& \frac{\partial \xi}{\partial t}=-\frac{y v(t)}{l^{2}(t)}=-\xi \frac{v(t)}{l(t)}
\end{aligned}
$$


式（11）を式（8）に代入すると次式となる.

$$
w(y, t)=\sum_{j=1}^{N} q_{j}(t) \varphi_{j}(\xi)+\xi f_{\mathrm{car}}(t)
$$

式（18）の各種導関数は以下のように表される.

$$
\begin{aligned}
\frac{\partial w(y, t)}{\partial y}= & \frac{1}{l(t)} \sum_{j=1}^{N} q_{j}(t) \frac{\partial \varphi_{j}(\xi)}{\partial \xi}+\frac{1}{l(t)} f_{\mathrm{car}}(t) \\
\frac{\partial^{2} w(y, t)}{\partial y^{2}}= & \frac{1}{l^{2}(t)} \sum_{j=1}^{N} q_{j}(t) \frac{\partial^{2} \varphi_{j}(\xi)}{\partial \xi^{2}} \\
\frac{\partial w(y, t)}{\partial t}= & \sum_{j=1}^{N} \frac{\partial q_{j}(t)}{\partial t} \varphi_{j}(\xi)-\xi \frac{v(t)}{l(t)} \sum_{j=1}^{N} q_{j}(t) \frac{\partial \varphi_{j}(\xi)}{\partial \xi}-\xi \frac{v(t)}{l(t)} f_{\mathrm{car}}(t)+\xi \frac{\partial f_{\mathrm{car}}(t)}{\partial t} \\
\frac{\partial^{2} w(y, t)}{\partial t^{2}}= & \sum_{j=1}^{N} \frac{\partial^{2} q_{j}(t)}{\partial t^{2}} \varphi_{j}(\xi)-2 \xi \frac{v(t)}{l(t)} \sum_{j=1}^{N} \frac{\partial q_{j}(t)}{\partial t} \frac{\partial \varphi_{j}(\xi)}{\partial \xi}+\xi\left(\frac{2 v^{2}(t)}{l^{2}(t)}-\frac{a(t)}{l(t)}\right)_{j=1}^{N} q_{j}(t) \frac{\partial \varphi_{j}(\xi)}{\partial \xi} \\
& +\frac{\xi^{2} v^{2}(t)}{l^{2}(t)} \sum_{j=1}^{N} q_{j}(t) \frac{\partial^{2} \varphi_{j}(\xi)}{\partial \xi^{2}}+\xi\left(\frac{2 v^{2}(t)}{l^{2}(t)}-\frac{a(t)}{l(t)}\right) f_{\mathrm{car}}(t)-2 \xi \frac{v(t)}{l(t)} \frac{\partial f_{\mathrm{car}}(t)}{\partial t}+\xi \frac{\partial^{2} f_{\mathrm{car}}(t)}{\partial t^{2}} \\
\frac{\partial^{2} w(y, t)}{\partial y \partial t}= & \frac{1}{l(t)} \sum_{j=1}^{N} \frac{\partial q_{j}(t)}{\partial t} \frac{\partial \varphi_{j}(\xi)}{\partial \xi}-\frac{v(t)}{l^{2}(t)} \sum_{j=1}^{N} q_{j}(t) \frac{\partial \varphi_{j}(\xi)}{\partial \xi}-\frac{v(t)}{l^{2}(t)} \sum_{j=1}^{N} q_{j}(t) \xi \frac{\partial^{2} \varphi_{j}(\xi)}{\partial \xi^{2}}-\frac{v(t)}{l^{2}(t)} f_{\mathrm{car}}(t) \\
& +\frac{1}{l(t)} \frac{\partial f_{\mathrm{car}}(t)}{\partial t}
\end{aligned}
$$

これらを式（3）に代入して整理すると次式となる.

$$
\begin{aligned}
& \rho \sum_{j=1}^{N} \frac{\partial^{2} q_{j}(t)}{\partial t^{2}} \varphi_{j}(\xi)+2 \rho \frac{v(t)}{l(t)}(1-\xi) \sum_{j=1}^{N} \frac{\partial q_{j}(t)}{\partial t} \frac{\partial \varphi_{j}(\xi)}{\partial \xi}+c_{\mathrm{p}} \sum_{j=1}^{N} \frac{\partial q_{j}(t)}{\partial t} \varphi_{j}(\xi) \\
& +\rho\left(\frac{a(t)}{l(t)}(1-\xi)-\frac{2 v^{2}(t)}{l^{2}(t)}(1-\xi)-\frac{g-a(t)}{l(t)}\right) \sum_{j=1}^{N} q_{j}(t) \frac{\partial \varphi_{j}(\xi)}{\partial \xi}+c_{\mathrm{p}} \frac{v(t)}{l(t)}(1-\xi) \sum_{j=1}^{N} q_{j}(t) \frac{\partial \varphi_{j}(\xi)}{\partial \xi} \\
& +\frac{1}{l^{2}(t)}\left\{\rho v^{2}(t)(1-\xi)^{2}-\frac{m_{\mathrm{cs}}}{2} g-\rho l(t)(g-a(t)) \xi-u(t)\right\} \sum_{j=1}^{N} q_{j}(t) \frac{\partial^{2} \varphi_{j}(\xi)}{\partial \xi^{2}}+\rho \xi \frac{\partial^{2} f_{\mathrm{car}}(t)}{\partial t^{2}} \\
& +\left\{2 \rho(1-\xi) \frac{v(t)}{l(t)}+c_{\mathrm{p}} \xi\right\} \frac{\partial f_{\mathrm{car}}(t)}{\partial t}+\left\{\rho(1-\xi)\left(\frac{a(t)}{l(t)}-\frac{2 v^{2}(t)}{l^{2}(t)}\right)+c_{\mathrm{p}} \frac{v(t)}{l(t)}(1-\xi)-\rho \frac{g-a(t)}{l(t)}\right\} f_{\mathrm{car}}(t)=0
\end{aligned}
$$


両辺に $\varphi_{i}(\xi) d \xi$ を掛け，0から 1 の区間で積分すると運動方程式は次のように得られる.

$$
\mathbf{M} \ddot{\mathbf{q}}+\mathbf{C} \dot{\mathbf{q}}+(\mathbf{K}+\boldsymbol{\beta} u) \mathbf{q}=\mathbf{f}
$$

$$
\mathbf{q}=\left[\begin{array}{lll}
q_{1}(t) & \cdots & q_{N}(t)
\end{array}\right]^{T}
$$

ここで $\mathbf{q}$ は一般化座標の応答ベクトルであり, ドットは時間 $t$ での微分を表す. $\mathbf{M}, \mathbf{C}, \mathbf{K}$ はそれぞれ質量行列, 減衰行列, 剛性行列, $\boldsymbol{\beta} u$ は制御力行列, $\mathbf{f}$ は外力ベクトルである. 各ベクトルおよび行列の $i$ 行 $j$ 列の要素は, 三角関数の直交性を用いて, 次のように得られる。

$$
\begin{aligned}
& M_{i j}= \begin{cases}\rho, & i=j \\
0, & i \neq j\end{cases} \\
& C_{i j}=\left\{\begin{array}{l}
2 \rho \frac{v(t)}{l(t)} \int_{0}^{1}(1-\xi) \frac{\partial \varphi_{j}(\xi)}{\partial \xi} \varphi_{i}(\xi) d \xi+c_{\mathrm{p}}, \quad i=j \\
2 \rho \frac{v(t)}{l(t)} \int_{0}^{1}(1-\xi) \frac{\partial \varphi_{j}(\xi)}{\partial \xi} \varphi_{i}(\xi) d \xi,
\end{array}\right. \\
& \beta_{i j}=\left\{\begin{array}{l}
\frac{1}{l^{2}(t)}(j \pi)^{2}, \quad i \neq j \\
0, \quad+\rho \frac{v^{2}(t)}{l^{2}(t)} \int_{0}^{1}(1-\xi)^{2} \frac{\partial^{2} \varphi_{j}(\xi)}{\partial \xi^{2}} \varphi_{i}(\xi) d \xi-\rho \frac{g-a(t)}{l(t)} \int_{0}^{1} \xi \frac{\partial^{2} \varphi_{j}(\xi)}{\partial \xi^{2}} \varphi_{i}(\xi) d \xi \\
\quad+\frac{m_{\mathrm{cs}} g}{2 l^{2}(t)}(j \pi)^{2}, \\
\left(\begin{array}{ll}
\left.\frac{a(t)}{l(t)}-\frac{2 v^{2}(t)}{l^{2}(t)}\right) \int_{0}^{1}(1-\xi) \frac{\partial \varphi_{j}(\xi)}{\partial \xi} \varphi_{i}(\xi) d \xi+c_{\mathrm{p}} \frac{v(t)}{l(t)} \int_{0}^{1}(1-\xi) \frac{\partial \varphi_{j}(\xi)}{\partial \xi} \varphi_{i}(\xi) d \xi \\
\rho\left(\frac{a(t)}{l(t)}-\frac{2 v^{2}(t)}{l^{2}(t)}\right) \int_{0}^{1}(1-\xi) \frac{\partial \varphi_{j}(\xi)}{\partial \xi} \varphi_{i}(\xi) d \xi+c_{\mathrm{p}} \frac{v(t)}{l(t)} \int_{0}^{1}(1-\xi) \frac{\partial \varphi_{j}(\xi)}{\partial \xi} \varphi_{i}(\xi) d \xi \\
\quad+\rho \frac{v^{2}(t)}{l^{2}(t)} \int_{0}^{1}(1-\xi)^{2} \frac{\partial^{2} \varphi_{j}(\xi)}{\partial \xi^{2}} \varphi_{i}(\xi) d \xi-\rho \frac{g-a(t)}{l(t)} \int_{0}^{1} \xi \frac{\partial^{2} \varphi_{j}(\xi)}{\partial \xi^{2}} \varphi_{i}(\xi) d \xi
\end{array}\right.
\end{array}\right. \\
& K_{i j} \quad i \neq j
\end{aligned}
$$




$$
\begin{aligned}
f_{i}= & -\rho \frac{\partial^{2} f_{\mathrm{car}}(t)}{\partial t^{2}} \int_{0}^{1} \xi \varphi_{i}(\xi) d \xi-\frac{\partial f_{\mathrm{car}}(t)}{\partial t} \int_{0}^{1}\left\{2 \rho(1-\xi) \frac{v(t)}{l(t)}+c_{\mathrm{p}} \xi\right\} \varphi_{i}(\xi) d \xi \\
& -f_{\mathrm{car}}(t) \int_{0}^{1}\left\{\rho(1-\xi)\left(\frac{a(t)}{l(t)}-\frac{2 v^{2}(t)}{l^{2}(t)}\right)+c_{\mathrm{p}} \frac{v(t)}{l(t)}(1-\xi)-\rho \frac{g-a(t)}{l(t)}\right\} \varphi_{i}(\xi) d \xi
\end{aligned}
$$

解析モデルの諸元を表 1 に示寸.コンペンロープの線密度 $\rho$, かご室の最大加速度 $\left|a_{\max }\right|$ と最大速度 $\left|v_{\max }\right|$ は文献 (Kaczmarczyk et al., 2009)，かご室の加加速度|j|は文献(Kaczmarczyk and Picton, 2013)，（ｐ中文献(Benosman, 2014)か ら引用している. かご室の昇降加速度 $a(t)$ や速度 $v(t)$ の時刻歴については Kaczmarczyk and Picton の方法 (Kaczmarczyk and Picton, 2013)を参考に，上昇時および下降時について時刻歴を図 2,3 のように設定する. コンペ ンシーブの質量 $m_{\mathrm{cs}}$ については, $500 \mathrm{~kg}$ と $15000 \mathrm{~kg}$ のケースが Kaczmarczyk ら(Kaczmarczyk et al., 2009)によって, また $554 \mathrm{~kg}$ のケースが田中ら(田中他，2018)によって検討されている. 本論ではアクティブ制御力として張力を 加えるため, 軽量の $500 \mathrm{~kg}$ を選択寸る. ロープの最大長さ $l_{\max }$ は, 地震時のエレベータロープスウェイが報告さ れている超高層建物（60 階程度）のエレベータを想定して設定している. 考慮モード次数 $N$ にいて，コンペン ロープはメインロープと比較して張力が小さく, 2 次の固有振動数まで建物と共振する可能性があり, 少なくと

Table 1 Parameters of analysis model.

\begin{tabular}{lcc}
\hline \hline Parameter & Symbol & Value \\
\hline Mass of compensating sheave & $m_{\mathrm{cs}}$ & $500 \mathrm{~kg}$ \\
Mass per unit length & $\rho$ & $2.11 \mathrm{~kg} / \mathrm{m}$ \\
Damping coefficient per unit length & $c_{\mathrm{p}}$ & $0.0315 \mathrm{~N} \cdot \mathrm{s} / \mathrm{m}^{2}$ \\
Jerk & $|j|$ & $2.4 \mathrm{~m} / \mathrm{s}^{3}$ \\
Maximum acceleration & $\left|a_{\max }\right|$ & $1.2 \mathrm{~m} / \mathrm{s}^{2}$ \\
Maximum velocity & $\left|v_{\max }\right|$ & $8.0 \mathrm{~m} / \mathrm{s}$ \\
Minimum length of compensation rope & $l_{\min }$ & $5 \mathrm{~m}$ \\
Maximum length of compensation rope & $l_{\max }$ & $240 \mathrm{~m}$ \\
The number of ropes & - & 1 \\
The number of modes & $N$ & 5 \\
\hline
\end{tabular}

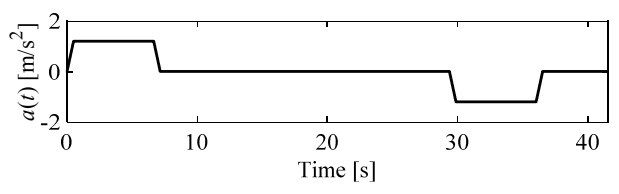

(a) Acceleration



(b) Velocity



(c) Position

Fig. 2 Upward motion of the car.

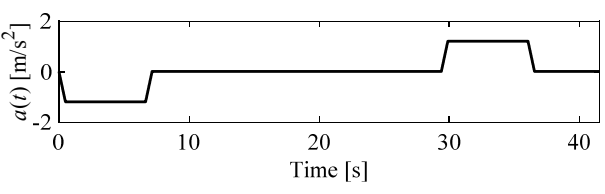

(a) Acceleration

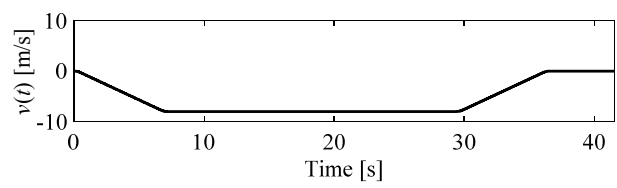

(b) Velocity

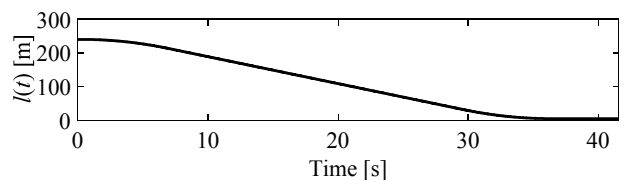

(c) Position

Fig. 3 Downward motion of the car. 
も 3 次の固有振動数までは考慮する必要があることが示されている(木村, 久久湊，2013). 振動中にロープ長の 変化する本研究においては, ロープ長によってはより高次のモードも含め励起される可能性があるため, $N=5$ と 設定している．なお， 3 章の制御設計においては，建物と共振する可能性のあるコンペンロープの 1 次および 2 次の固有振動数を用いて制御力 $u(t)$ を決定する.

\section{3. 制御設計}

かご室の昇降に基づいた制御力の決定方法について述べる. 式（1）より，コンペンロープの張力 $T(y, t)$ は，か ご室の昇降加速度 $a(t)$ に依存する. ここで, 長さ $l$, 張力 $T$, 密度 $\rho$ の弦の $i$ 次固有振動数は式 (32) で表される ため，コンペンロープの固有振動数はかご室の位置（コンペンロープの長さ）と加速度によって変動する.

$$
F_{i}=\frac{i}{2 l} \sqrt{\frac{T}{\rho}}
$$

コンペンロープの変動する固有振動数を外力の振動数とずらすため, 本論では鉛直方向の制御力（張力） $u(t)$ を 式（33）のように，かご室の位置と加速度に関するフィードバック制御力として与える. このとき，式（1）のコ ンペンロープの張力 $T(y, t)$ は式（34）となる.

$$
\begin{aligned}
& u(t)=\rho a(t) \frac{l(t)}{2}+T_{F_{1}} \\
& T(y, t)=\frac{m_{\mathrm{cs}}}{2} g+\rho y g+\rho a(t)\left\{\frac{l(t)}{2}-y\right\}+T_{F_{1}}
\end{aligned}
$$

すなわち, 式（33）の第 1 項でかご室の昇降に伴う張力の変動を打ち消し, 第 2 項で外力との共振を避けるよう に固有振動数を変化させる. ただし張力はロープの位置 $y$ により異なる. 制御力 $u(t)=0$ およびかご室の加速度 $a(t)=0$ としたときのロープ長と共振振動数の関係を求めるため, $F_{\mathrm{b}}$ を $0.1 \mathrm{~Hz}$ 刻みで変化させてロープの応答振 幅が極大となる最小の振動数を調べると, ロープ長が $60 \mathrm{~m}$ のとき $0.3 \mathrm{~Hz}, 240 \mathrm{~m}$ のとき $0.1 \mathrm{~Hz}$ という結果とな る. 式(32)より $i=1$ について $T=\left(2 l F_{1}\right)^{2} \rho$ なので，それぞれ張力は $2.7 \times 10^{3} \mathrm{~N}\left(0.35 \mathrm{~Hz}\right.$ で $\left.3.7 \times 10^{3} \mathrm{~N}\right), 4.9 \times 10^{3} \mathrm{~N}$ と計算できる. 一方, 各ロープ長において中央での張力は式(1)より $T(l / 2, t)=\left(m_{\mathrm{cs}}+\rho l\right) g / 2$ なので, それぞれ $3.1 \times 10^{3} \mathrm{~N}, 4.9 \times 10^{3} \mathrm{~N}$ と求められる. したがって本論で扱うロープについては中央部の張力でおおよそ模擬できる とし, $l(t) / 2$ としている. また, 式 (32) より, 張力 $T$ が一定であってもコンペンロープの長さ $l$ の変化により, 1 次固有振動数 $F_{1}$ は変動するため, $T_{F_{1}}$ によりこの変動を抑制する. $T_{F_{1}}$ は外力の特性により調整されることが望 ましい. 本論では建物が振動数 $F_{\mathrm{b}}$ で振動する場合について $T_{F_{1}}$ の值を導出する.

まず，コンペンロープの固有振動数 $F_{i}(i=1,2, \cdots)$ を建物の振動数 $F_{\mathrm{b}}$ より高く取ることで, 共振を避けるこ とを考え，次の不等式を設定する.

$$
F_{1}(t)=\frac{1}{2 l(t)} \sqrt{\frac{T\left(\frac{l(t)}{2}, t\right)}{\rho}}>F_{\mathrm{b}}
$$


式（34）より

$$
T\left(\frac{l(t)}{2}, t\right)=\frac{m_{\mathrm{cs}}+\rho l(t)}{2} g+T_{F_{1}}
$$

なので，これを式（35）に代入すると次式が得られる.

$$
T_{F_{1}}>4 \rho\left(l(t) F_{\mathrm{b}}\right)^{2}-\frac{m_{\mathrm{cs}}+\rho l(t)}{2} g
$$

ここで正の定数 $T_{\text {const }}$ を用いると， $T_{F_{1}}$ は次のように書くことができる.

$$
T_{F_{1}}=4 \rho\left(l(t) F_{\mathrm{b}}\right)^{2}-\frac{m_{\mathrm{cs}}+\rho l(t)}{2} g+T_{\text {const }}
$$

したがって，制御力は式（39）となる.

$$
u(t)=4 \rho\left(l(t) F_{\mathrm{b}}\right)^{2}+\frac{\rho l(t)(a(t)-g)-m_{\mathrm{cs}} g}{2}+T_{\text {const }}
$$

ただし， $u(t)<0$ のとき，すなわちコンペンシーブを押し上げる上向きの力となるときは，シーブからのロープの 外れを誘発する可能性があるため $u(t)=0$ とする. 上記の方法を取る場合，張力を無限に大きくすることで振動は 抑えられるが現実的ではない，また，大きな張力を継続的に加えることはロープヘのダメージとなることが考え られる.

そこで次に，コンペンロープの 1 次固有振動数 $F_{1}$ のみを建物の振動数 $F_{\mathrm{b}}$ より低く取ることで，共振を避ける ことを考え，次の不等式を設定する.

$$
F_{1}(t)=\frac{1}{2 l(t)} \sqrt{\frac{T\left(\frac{l(t)}{2}, t\right)}{\rho}}<F_{\mathrm{b}}
$$

同様に解くと次式が得られる.

$$
T_{F_{1}}<4 \rho\left(l(t) F_{\mathrm{b}}\right)^{2}-\frac{m_{\mathrm{cs}}+\rho l(t)}{2} g
$$

ただし，このときコンペンロープの 2 次固有振動数 $F_{2}$ が建物の振動数 $F_{\mathrm{b}}$ と共振する可能性があるため, 次の不 等式を条件に加える. 


$$
F_{2}=\frac{1}{l(t)} \sqrt{\frac{T\left(\frac{l(t)}{2}, t\right)}{\rho}}>F_{\mathrm{b}}
$$

すなわち

$$
T_{F_{1}}>\rho\left(l(t) F_{\mathrm{b}}\right)^{2}-\frac{m_{\mathrm{cs}}+\rho l(t)}{2} g
$$

したがって $1<\alpha<4$ を用いて $T_{F_{1}}$ は式（44）で表される.

$$
T_{F_{1}}=\alpha \rho\left(l(t) F_{\mathrm{b}}\right)^{2}-\frac{m_{\mathrm{cs}}+\rho l(t)}{2} g
$$

このとき制御力は次式となる.

$$
u(t)=\alpha \rho\left(l(t) F_{\mathrm{b}}\right)^{2}+\frac{\rho l(t)(a(t)-g)-m_{\mathrm{cs}} g}{2}
$$

ただし， $u(t)<0$ のきはシーブからのロープの外れを誘発する可能性があるため $u(t)=0$ とする.

なお，本論の制御則は制御対象であるコンペンロープに対しては，その応答を参照しないフィードフォワード 系であり，制御結果を保証するために，簡単な計測で実現できるフィードバック制御との併用を今後考える必要 がある。

\section{4. 振動制御効果の検証}

本論では固有周期 5.6 秒 $\left(=1 / F_{\mathrm{b}}\right)$ の超高層建物（240 m 級）の最上階が式 (46) で表される正弦波振動を定常 的に続ける場合を考える. 振幅について, 振幅 $0.1 \mathrm{~m} / \mathrm{s}^{2}$ の周期 5.6 秒の加速度に対する変位振幅は $0.079 \mathrm{~m}$ であ る. 一方, 既往研究(Kaczmarczyk and Picton, 2013)では $0.25 \mathrm{~m}$ （高さ $137.75 \mathrm{~m}$ 地点）の変位振幅を想定している. 本論ではより応答が大きくなるケースとして後者を採用し，本論で想定する建物高さに合わせ， $0.44 \mathrm{~m}$ (高さ 240 $\mathrm{m}$ 地点）とする．これは建物の層間変形が一様であるとすると，変形角 $0.0018 \mathrm{rad}(<1 / 200 \mathrm{rad})$ となる振動であ る.

$$
f_{\mathrm{b}}(t)=0.44 \sin \frac{2 \pi}{5.6} t[\mathrm{~m}]
$$

このとき, かご室の変位 $f_{\mathrm{car}}(t)$ は，かご室の昇降により参照する建物部位が変化するため，本論では次の近似式 (Benosman, 2014)を用いる.

$$
f_{\text {car }}(t)=f_{\mathrm{b}}(t) \sin \frac{\pi l(t)}{2 l_{\max }}
$$


本論では(a)かご室が最下階から最上階へ上昇するときおよび(b)かご室が最上階から最下階へ下降するときの 2 ケースについて検討を行った. 数值計算にはニューマーク $\beta$ 法 $(\beta=1 / 4)$ を用い, 解析の時間刻多は 0.01 秒とし

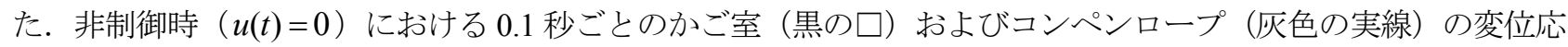
答の軌跡を図 4 に示す．図 4 より，同じ外力を受ける場合でも，かご室の移動方向により最大振幅や応答形状が 異なることが確認できる.このときのコンペンロープの 1 次および 2 次の固有振動数 $F_{1}$ および $F_{2}($ 張力 $T(l(t) / 2, t)$ を用いて算出）と外力の振動数 $F_{\mathrm{b}}$ の時刻歴を図 5 に示寸. 図 5 より, ロープ長 $l(t)$ の変化に伴い $F_{1}$ および $F_{2}$ が変 化していることが確認できる．また，ロープ長が $l_{\max } / 2$ 程度のとき $F_{\mathrm{b}}$ と $F_{1}$ が，ロープ長が長いとき $F_{\mathrm{b}}$ と $F_{2}$ が 近接しており, 1 次 2 次ともに共振の可能性が考えられる（ロープ長の変化は図 2,3(c)参照).

次にアクティブ振動制御の効果を検証するために, 非制御および $T_{\text {const }}=0,13500[\mathrm{~N}]$ を用いて制御を行った場 合について，コンペンロープの最大振幅の時刻歴を図 6 に，制御力の時刻歴を図 7 に示す。なお，図 6 では各時 刻 $t$ におけるコンペンロープ全体 $\left(l_{\min } \leq y \leq l(t)\right)$ での相対変位応答の絶対值の最大值 $\max _{y}|\bar{w}(y, t)|$ をプロット しているため, 各時刻において最大值をとる $y$ は異なる. $T_{\text {const }}=0[\mathrm{~N}]$ は式 $(38)$ より共振状態 $\left(F_{1}(t)=F_{\mathrm{b}}\right)$ と なるため, 図 6 において応答が制御時のほうが大きくなっている. $T_{\text {const }}=13500[\mathrm{~N}]$ は降下時の最大応答が非制 御時よりも改善される場合として掲載した. このときの制御力は図 7 に示寸ように $11.0 \sim 24.1 \mathrm{kN}$ と大きく, ロー プに加え続けることは現実的ではないと考えられる. $T_{\text {const }}=13500[\mathrm{~N}]$ では, 大きな張力を付加することにより, 図 8 に示すように 1 次固有振動数 $F_{1}$ を常に $F_{\mathrm{b}}$ よりも大きくすることができている.

続いて， $\alpha=2,3 \quad(1<\alpha<4)$ を用いて制御を行った場合について，コンペンロープの最大振幅の時刻歴を図 9 に, 制御力の時刻歴を図 10 に, 固有振動数の変化を図 11 に示寸. 図 10,11 より, 制御力を加えることで 2 次 の共振を防いでいることが確認できる. 一方図 10 より，制御力が 0 となる時間が $T_{\text {const }}$ を用いた場合より長くな っていることが確認できる. これは図 11 より $F_{1}(t)<F_{\mathrm{b}}$ とするためには, $u(t)<0$ が必要となるためである. 本論 で使用寸る制御力は張力であり, 固有振動数を高める方向に作用寸る. したがって, 外力の振動数 $F_{\mathrm{b}}$ に対してコ ンペンロープを低振動数化して共振回避することはできない. すなわち, 図 5 に示寸非制御時の 1 次および 2 次 の固有振動数を下げる（張力を低減する）ことはできない，そのため，大きな張力を加えることでコンペンロー プの固有振動数を外力の振動数よりも高める（例えば $T_{\text {const }}=13500[\mathrm{~N}]$ ）ことによる共振回避を除いて, 必ず 1 次 の固有振動数 $F_{1}$ は $F_{\mathrm{b}}$ と交差し, その際に応答が増幅する傾向がある. 図 $9(\mathrm{~b}) の \alpha=2$ では, 時刻 10 秒前後にお いて応答が増幅している。これはロープ長の長い時刻において, 非制御時には 2 次の振動モードで共振していた が，張力を加えることで 1 次モード成分も励起されたためと考えられる．かご室の昇降に伴い変化するロープ長 によって, どちらの振動数からどの程度外すのが良いか検討し, 設計変数 $\alpha$ の最適化あるいはスケジューリング が今後必要である.

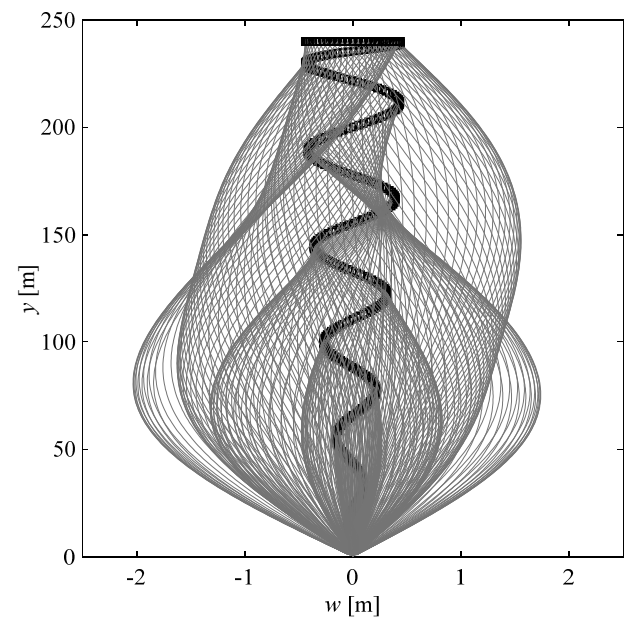

(a) Upward motion of the car.

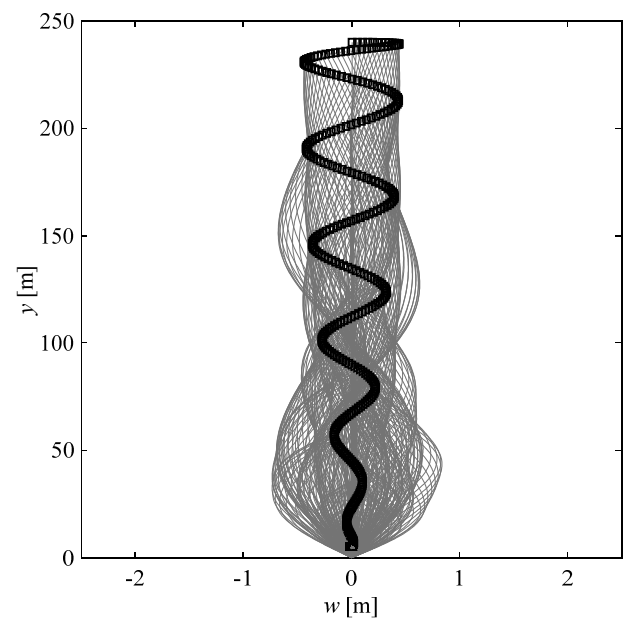

(b) Downward motion of the car.

Fig. 4 Dynamic response of the compensation rope in passive condition. The gray curves describe compensation rope shapes. Each car position is denoted by a square in the figure. Although the building continues the same vibration in both figures, the rope responses are quite different between upward and downward cases. 


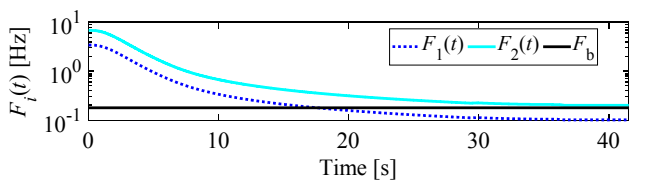

(a) Upward motion of the car.

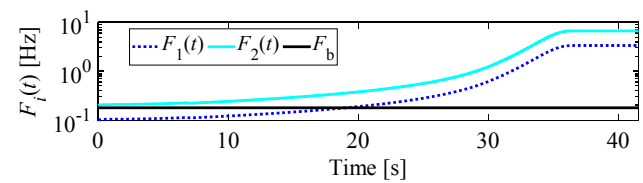

(b) Downward motion of the car.

Fig. 5 Time history of natural frequencies (Passive). $F_{\mathrm{b}}, F_{1}$, and $F_{2}$ are frequency of external force, 1 st and 2nd mode natural frequencies of the compensation rope, respectively. $F_{1}$ intersects with $F_{\mathrm{b}}$ around $20 \mathrm{~s}$, and $F_{2}$ closes to $F_{\mathrm{b}}$ when the compensation rope is long in both figures. Thus, two resonances can occur.
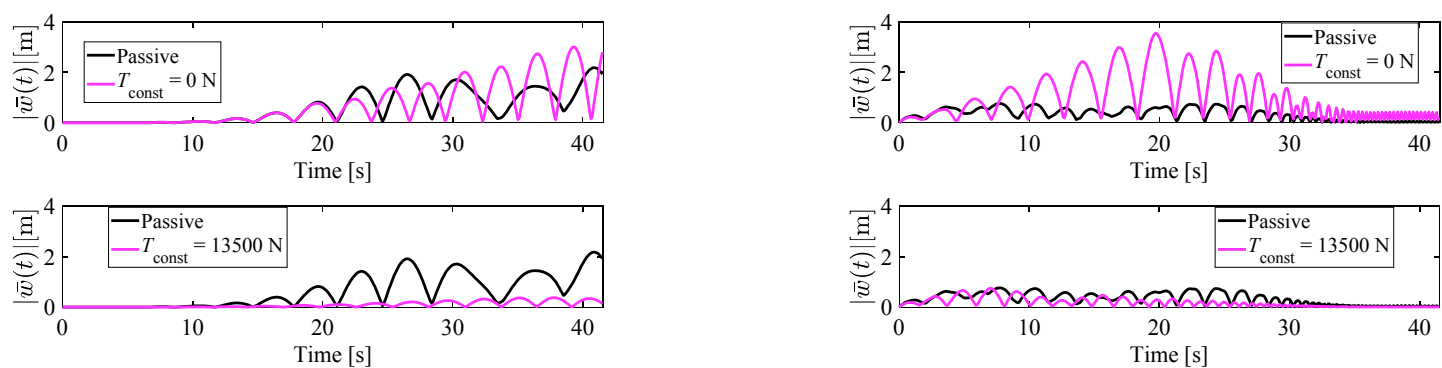

(a) Upward motion of the car.

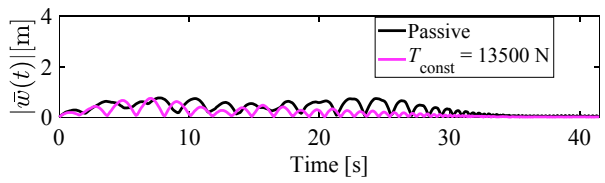

(b) Downward motion of the car.

Fig. 6 Maximum displacement of the compensation rope is shown in the form of time history. The responses in passive and active conditions $\left(T_{\text {const }}=0[\mathrm{~N}]\right.$ and $\left.13500[\mathrm{~N}]\right)$ are plotted with the black and pink curves, respectively. As the $T_{\text {const }}=0[\mathrm{~N}]$ case represents resonant condition, the response becomes quite large.

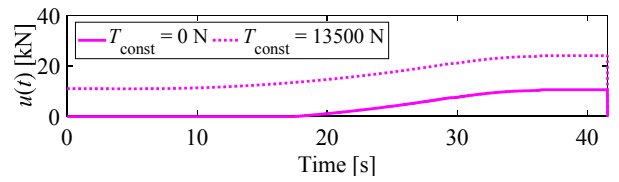

(a) Upward motion of the car.

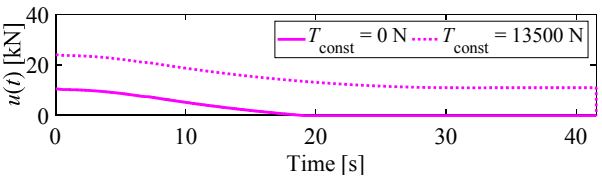

(b) Downward motion of the car.

Fig. 7 Time history of control force corresponding to Fig. 6.

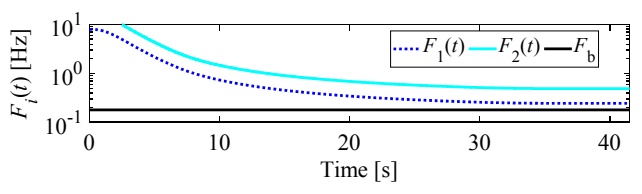

(a) Upward motion of the car.

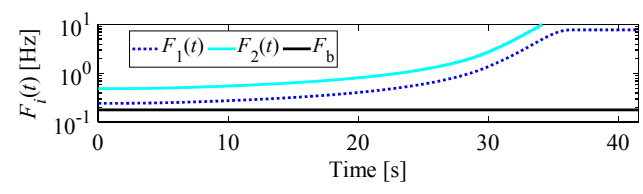

(b) Downward motion of the car.

Fig. 8 Time history of natural frequencies $\left(T_{\text {const }}=13500[\mathrm{~N}]\right)$. By adding large tension, $F_{1}$ and $F_{2}$ become bigger than $F_{\mathrm{b}}$ and the compensation rope avoids resonance.
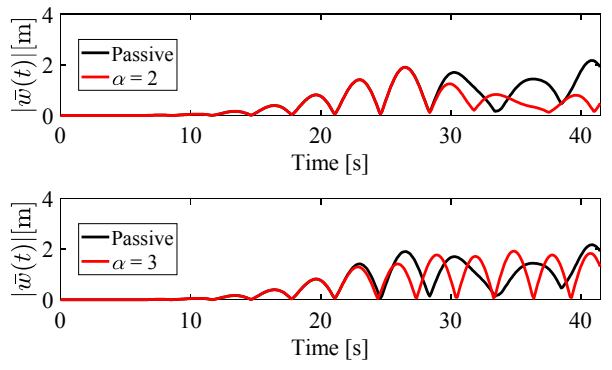

(a) Upward motion of the car.
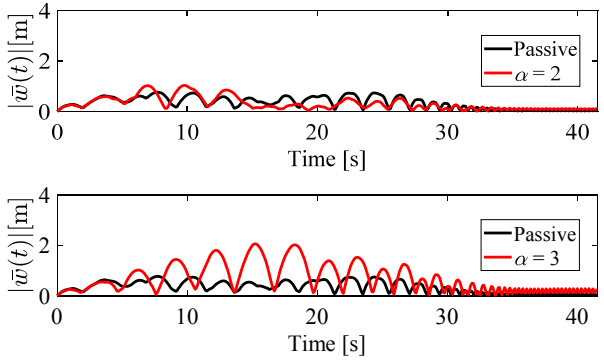

(b) Downward motion of the car.

Fig. 9 Maximum displacement of the compensation rope is shown in the form of time history. The responses in passive and active conditions ( $\alpha=2$ and 3) are plotted with the black and red curves, respectively. 


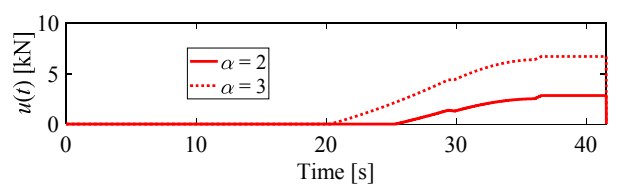

(a) Upward motion of the car.

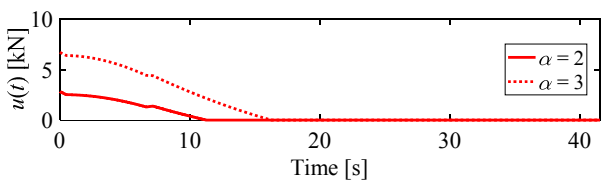

(b) Downward motion of the car.

Fig. 10 Time history of control force corresponding to Fig. 9.

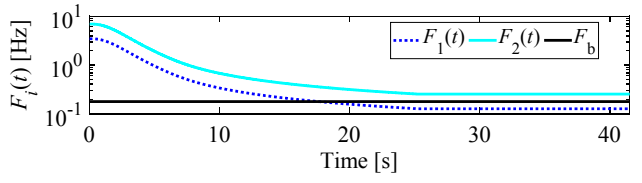

(a) Upward motion of the car.

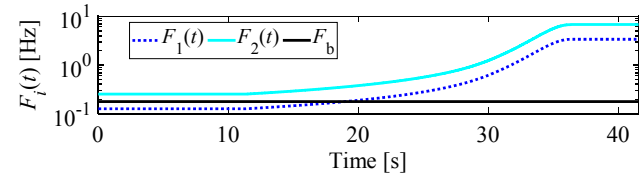

(b) Downward motion of the car.

Fig. 11 Time history of natural frequencies $(\alpha=2) . F_{2}$ becomes bigger and avoids resonance by control force. By contrast, as control force cannot take negative value, $F_{2}$ intersects with $F_{\mathrm{b}}$.

最後に図 12〜14 に，一定の張力を加え続けた場合の性能を示す. 図に示した $u=24.1[\mathrm{kN}]$ は $T_{\text {const }}=13500[\mathrm{~N}]$ で の最大制御力, $u=2.8[\mathrm{kN}]$ は $\alpha=2$ での最大制御力であり, 図 6,9 において比較的良好な性能を示したものとして 選択した. なお，一定の張力を加え続けた場合，与える張力が大きいほどロープの変位応答は抑えられる. 本論 では提案制御則と同レベルの制御力での性能比較という位置づけで，比較は提案制御則で使用した制御力の最大 值での場合に留めた， $u=24.1[\mathrm{kN}]$ にいては，大きな張力を加えることにより図 13 に示すように共振を回避し ているが， $T_{\text {const }}=13500$ [N]で述べたように現実的ではない. 一方， $u=2.8[\mathrm{kN}]$ ていて図 11 と図 14 を比較する と，共振に関する性能については大きな差がないように見えるものの，図 9 と図 12 を比較すると応答は制御則 にしたがって部分的に入力した $\alpha=2$ の場合と比較して悪い. これは張力を $\alpha=2$ における最大值で常に加えるこ とにより $F_{1}$ が昇降過程全体で大きくなり，ロープ長がより長い時刻で $F_{1}$ と $F_{\mathrm{b}}$ が交差したためと考えられる.

以上より，本論で提案するかご室の位置と加速度情報を用いた共振回避に基づく張力制御は，一定の応答低減 効果があることが確認できた.

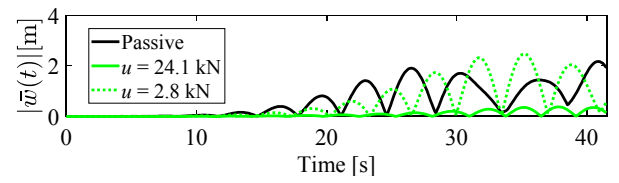

(a) Upward motion of the car.

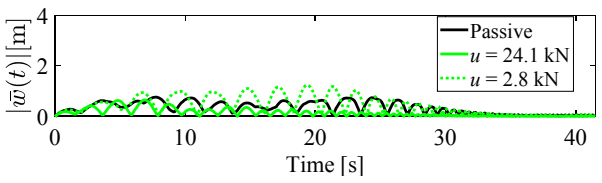

(b) Downward motion of the car.

Fig. 12 Maximum displacement of the compensation rope is shown in the form of time history. The responses in passive and constant tension conditions $(u=24.1[\mathrm{kN}]$ and $2.8[\mathrm{kN}])$ are plotted with the black and green curves, respectively. $u=24.1$ $[\mathrm{kN}]$ and $2.8[\mathrm{kN}]$ are the maximum values of control force for $T_{\text {const }}=13500[\mathrm{~N}]$ and $\alpha=2$.

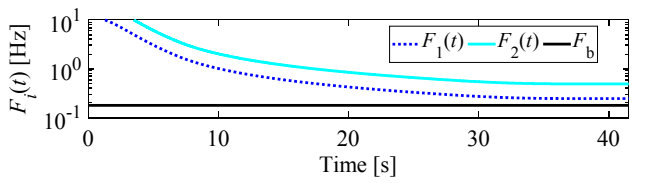

(a) Upward motion of the car.

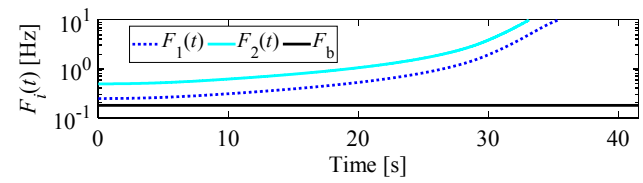

(b) Downward motion of the car.

Fig. 13 Time history of natural frequencies $(u=24.1[\mathrm{kN}])$. By adding large tension constantly, $F_{1}$ and $F_{2}$ become bigger than $F_{\mathrm{b}}$ and the compensation rope avoids resonance.

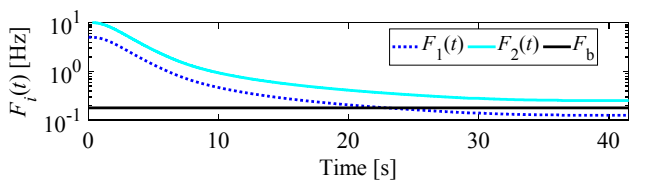

(a) Upward motion of the car.

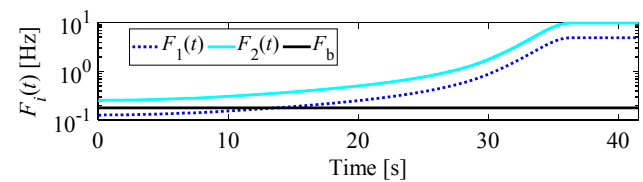

(b) Downward motion of the car.

Fig. 14 Time history of natural frequencies $(u=2.8[\mathrm{kN}])$. 


\section{5. 結 言}

本論では，かご室の位置および加速度の情報のみを用いて制御力（張力）を加えるコンペンロープの振動抑制 方法について提案し，その効果を建物が 1 次固有振動数で正弦波振動する場合について検証した．コンペンロー プと建物の共振回避に基づく制御により, 部分的な制御入力でロープの振動応答を効果的に低減できた.一方で, 安全面を考え, 張力を減少させる方向の制御力を使用しない制御器を想定した本手法では, 外力の振動数が比較 的小きい場合には，応答の低減効果はあまり期待できないことが明らかとなった.

今後, 建物の地震応答を外力とする場合や建物規模の異なる場合を考えていくにあたり, 制御の設計変数 $\alpha$ の 最適化あるいはスケジューリングを行う必要がある．また，昇降以前にロープが摇れている場合についても検討 する予定である。

\section{謝 辞}

本研究は JSPS 科研費 16K18186 の助成を受けたものである．記して謝意を表する．

\section{文献}

Benosman, M., Lyapunov-based control of the sway dynamics for elevator ropes with time-varying lengths, IFAC Proceedings Volumes, Vol.47, Issue3 (2014), pp.5592-5597.

社団法人日本エレベータ協会, 東北地方太平洋沖地震などの昇降機被害調査報告, エレベータ界, Vol.47, No.185 (2012), pp.4-8.

Kaczmarczyk, S., Iwankiewicz, R. and Terumichi, Y., The dynamic behaviour of a non-stationary elevator compensating rope system under harmonic and stochastic excitations, Journal of Physics: Conference Series, Vol.181, No.1 (2009), pp.1-8, DOI:10.1088/1742-6596/181/1/012047.

Kaczmarczyk, S. and Picton, P., The prediction of nonlinear responses and active stiffness control of moving slender continua subjected to dynamic loadings in a vertical host structure, International Journal of Acoustics and Vibration, Vol.18, No.1 (2013), pp.39-44.

木村弘之, エレベータ・ロープの摇れ解析について(特別講演 II), 昇降機・遊戯施設等の最近の技術と進歩技術講 演会講演論文集 (2013), pp.7-14.

木村弘之, 久々湊峰也, エレベータ・ロープの地震時摇れ検出のための簡易計算法 (張力分布の影響を考慮した場 合），日本機械学会論文集 C 編, Vol.79, No.801 (2013), pp.1237-1246.

三浦奈々子, 小檜山雅之, 地震動強度と応答レベルに順応する超高層建物・エレベータ連成系の可変ゲインフィ ードバック制御，日本建築学会構造系論文集, Vol.76, No.670 (2011), pp.2069-2076, DOI:10.3130/aijs.76.2069.

Nguyen, X. T., Miura, N. and Sone, A., Analysis and control of compensation rope response in elevator system with timevarying length, Proceedings of the 2017 Asian Control Conference (2017), pp.905-910.

大槻真嗣, 吉田和夫, 中川俊明, 木村弘之, 藤本滋, エレベータロープのロバスト振動制御，日本機械学会論文集 C 編, Vol.71, No.703 (2005), pp.859-866.

田中寛也, 石井麻美, 藤田聡, 田中和宏, 小川要一, リスク情報を用いた中間乗換え階によるロープ応答低減の有 効性検討に関する基礎的研究, 昇降機・遊戯施設等の最近の技術と進歩技術講演会講演論文集, Paper No.103 (2018), pp.9-14.

東京消防庁，高層建築物等における歩行困難者等に係る避難安全対策 (online), available from $<$ http://www.tfd.metro.tokyo.jp/hp-yobouka/high-rise.html>, (参照日 2017 年 10 月 19 日).

\section{References}

Benosman, M., Lyapunov-based control of the sway dynamics for elevator ropes with time-varying lengths, IFAC Proceedings Volumes, Vol.47, Issue3 (2014), pp.5592-5597.

Japan Elevator Association, Tohoku-chiho taiheiyo oki jishin nado no shokoki higai chosa hokoku, Elevator World, Vol.47, No.185 (2012), pp.4-8 (in Japanese).

Kaczmarczyk, S., Iwankiewicz, R. and Terumichi, Y., The dynamic behaviour of a non-stationary elevator compensating rope system under harmonic and stochastic excitations, Journal of Physics: Conference Series, Vol.181, No.1 (2009), pp.1-8, 
DOI:10.1088/1742-6596/181/1/012047.

Kaczmarczyk, S. and Picton, P., The prediction of nonlinear responses and active stiffness control of moving slender continua subjected to dynamic loadings in a vertical host structure, International Journal of Acoustics and Vibration, Vol.18, No.1 (2013), pp.39-44.

Kimura, H., Elevator rope no yure-kaiseki ni tsuite (Tokubetsu koen II), Proceedings of the Elevator, Escalator and Amusement Rides Conference (2013), pp.7-14 (in Japanese).

Kimura, H. and Kuguminato, T., Simplified calculation method for detecting elevator rope deflection during earthquake (Considering the distribution of rope tension), Transactions of the Japan Society of Mechanical Engineers, Series C, Vol.79, No.801 (2013), pp.1237-1246 (in Japanese).

Miura, N. and Kohiyama, M., Variable gain feedback control of a high-rise building-elevator system adjusted to ground motion intensity and response level, Vol.76, No.670 (2011), pp.2069-2076, DOI:10.3130/aijs.76.2069 (in Japanese).

Nguyen, X. T., Miura, N. and Sone, A., Analysis and control of compensation rope response in elevator system with timevarying length, Proceedings of the 2017 Asian Control Conference (2017), pp.905-910.

Otsuki, M., Yoshida, K., Nakagawa, T., Kimura, H. and Fujimoto, S., Nonstationary robust control for vibration of elevatorrope, Transactions of the Japan Society of Mechanical Engineers, Series C, Vol.71, No.703 (2005), pp.859-866 (in Japanese).

Tanaka, H., Ishii, A., Fujita, S., Tanaka, K. and Ogawa, Y., Fundamental study on effectiveness evaluation of rope response reduction by intermediate transit floor using risk information, Proceedings of the Elevator, Escalator and Amusement Rides Conference, Paper No.103 (2018), pp.9-14 (in Japanese).

Tokyo Fire Department, Kousoukenchikubutsu-tou ni okeru hokoukonnansya-tou ni kakawaru hinananzen-taisaku (online), available from <http://www.tfd.metro.tokyo.jp/hp-yobouka/high-rise.html>, (accessed on 19 October, 2017) (in Japanese). 